\title{
Knowledge and Awareness of Osteoporosis among Saudi Physicians and Nurses: A Cross-Sectional Study
}

\author{
Mushabab Ayed Alghamdi ${ }^{1}$, Abdel Gaffar AbdelAllah Mohammed ${ }^{2 *}$ \\ ${ }^{1}$ College of Medicine, University of Bisha, Bisha, Saudi Arabia; ${ }^{2}$ Division of Rheumatology, Department of Medicine, $\mathrm{J} 47 \mathrm{Old}$ \\ Main Building, Groote Schuur Hospital, University of Cape Town, Observatory, Cape Town, South Africa
}

Abstract

Citation: Alghamdi MA, Mohammed AGA. Knowledge and Awareness of Osteoporosis among Saudi Physicians and Nurses. A Cross-Sectional Study. Open Access Maced J Med Sci. 2018 May 20; 6(5):913-916 Keywords: Osteoporosis; Health professionals; Awareness; Knowledge; Saudi

*Correspondence: Abdel Gaffar AbdelAllah Mohammed. Division of Rheumatology, Department of Medicine, $J 47$ Old Main Building, Groote Schuur Hospital, University of Cape Town, Observatory, Cape Town, South Africa. E-

Received: 25-Jan-2018; Revised: 23-Mar-2018; Accepted: 24-Mar-2018; Online first: 15-May-2018 Copyright: () 2018 Mushabab Ayed Alghamdi, Abde Gaffar AbdelAllah Mohammed. This is an open-access article distributed under the terms of the Creative Commons Attribution-NonCommercial 4.0 Internation

Funding: This research did not receive any financial

AIM: We aimed to evaluate the awareness and knowledge of osteoporosis in a sample of 141 health professionals.

MATERIALS AND METHODS: A group of 141 health professionals (medical, surgical, primary health care and nursing departments) were enrolled in this cross-sectional study in the period from August 2017 to November 2017. The participants completed a questionnaire composed of 19 questions about osteoporosis which covering the main domains of knowledge on osteoporosis. Each correct answer carried 1 point whereas incorrect or 'don't know' carried 0 points. This gave a total score range of $0-19$. A cut-off level of $<10$ points was considered as poor knowledge while $\geq 10$ was regarded as good knowledge.

RESULTS: Out of 141 respondents, 78 were females, 63 males, mean age of the participants was $38.17 \pm 9.6$ years, less than 40 years $(n=89)$, more than 40 years $(n=52)$. Nurses $(n=54)$, medical $(n=29)$, surgical $(n=$ $35)$, primary health care $(n=23)$. Most of the study group with experience of fewer than 10 years $(n=66), 127$ $(90.1 \%)$ had good knowledge and $14(9.9 \%)$ had poor knowledge $p$-value $<0.01$

CONCLUSION: Our study revealed that Saudi health professionals have a good of knowledge about osteoporosis and no significant difference in osteoporosis knowledge between the health professional subgroups.

\section{Introduction}

Osteoporosis is defined as a systemic bone disease characterised by decreased bone mass and deterioration of micro-architecture of bone tissue leading to increased risk of fracture [1]. Osteoporosis is a major health problem in both developed and developing countries [2], and it has been considered as the second most important health concern after heart diseases in developed countries [3].

Several studies from different countries have pointed out the lack of awareness of osteoporosis, its risk factors and measures of prevention not only among the general population but also among physicians [4] [5]. Thus expanding the knowledge and awareness of osteoporosis are important measures warranting better care of osteoporosis with subsequent improvement of life quality and decrease disease burden.

A recent study demonstrated that physician knowledge and education improve patient care and outcome [6]. It worth mentioning that there is a deficiency in the number of Saudi health professionals [7]. Therefore, adequate and updated knowledge of osteoporosis by health professionals is of great importance towards improving patient care.

This study aims to evaluate the knowledge and awareness of osteoporosis in 141 Saudi health professionals. 


\section{Methods}

This a cross-sectional study conducted at King Abdullah General Hospital in Bisha from August 2017 to November 2017. A total of 141 health professionals (medical, surgical, primary health care and nursing departments) were enrolled in the study. The participants were selected randomly. Ethical approval was sought from Human Research Ethics Committee at the University of Bisha. All participants were given oral informed consent. The data was collected using a structured questionnaire.

The following data were taken from each participant: age, gender, type of health profession and years of experience. The questionnaire also included 19 questions on osteoporosis knowledge, which cover the definition, risk factors, management, prevention and complications of osteoporosis. Each item has Yes, No, and "Do not know" options. The latter option was designed to avoid guessing. Each correct answer carried 1 point whereas incorrect or 'don't know' carried 0 points. This gave a total score range of 0-19. A cut-off level of $<10$ points were considered as poor knowledge while $\geq 10$ was regarded as good knowledge.

Statistical analysis was conducted using Statistica (version13.2). Descriptive statistics were used to demonstrate the characteristics of the study population. Continuous variables were expressed as mean \pm standard deviation whereas categorical variables were measured as frequency and percentages. Kolmogorov-Smirnov and Shapiro-Wilk $W$ test were used to determine nature of the distribution. Kruskal Wallis test was applied to assess the degree of knowledge among the different subgroups where the health profession, age group, gender, and experience were entered as dependent variable while the degree of knowledge was entered as an independent variable, statistical significance is considered as $\mathrm{P}<0.05$.

\section{Results}

The characteristics of respondents are shown in Table 1.

Table 1: Respondents characteristics

\begin{tabular}{lllc}
\hline Variable & Category & No & Percentage \\
\hline Age group & Less than 40 & 89 & 63.1 \\
& More than 40 & 52 & 36.8 \\
Gender & Male & 63 & 44.6 \\
& Female & 78 & 55.3 \\
Speciality & Medical & 29 & 20.5 \\
& Surgical & 35 & 24.8 \\
& Primary care & 23 & 16.3 \\
Experience & Nurse & 54 & 38.2 \\
& Less than 10 & 66 & 46.8 \\
& 10-20 & 57 & 40.4 \\
& More than 20 & 18 & 12.7 \\
\hline
\end{tabular}

The mean age of the participants was $38.17 \pm$ 9.6 years. Concerning their age group, the majority were less than 40 years $(n=89)$, more than 40 years $(n=52)$. In terms of gender, the majority were females $(n=78)$, males $(n=63)$. A large number of the respondents were nurses $(n=54)$, medical $(n=29)$, surgical $(n=35)$, primary health care $(n=23)$. Respondents with experience of fewer than 10 years were greater than other groups $(n=66)$ (see Table 1). Responses to osteoporosis questions are shown in Table 2.

Table 2: Responses to the questionnaire questions

\begin{tabular}{|c|c|c|c|}
\hline Question & $\begin{array}{l}\text { Correct } \\
\text { No/\%) }\end{array}$ & $\begin{array}{l}\text { Incorrect } \\
(\mathrm{No} / \%)\end{array}$ & $\begin{array}{c}\text { Do not know } \\
(\mathrm{No} / \%)\end{array}$ \\
\hline $\begin{array}{l}\text { Pain is common in individual with } \\
\text { osteoporosis }\end{array}$ & $56(39.7 \%)$ & $80(56.7 \%)$ & $53.5 \%)$ \\
\hline $\begin{array}{l}\text { Osteoporosis is a condition } \\
\text { characterised by fragile bones }\end{array}$ & $130(92.1 \%)$ & 9 (6.3\%) & 2 (1.4\%) \\
\hline $\begin{array}{l}\text { Osteoporosis and osteomalcia are } \\
\text { different conditions }\end{array}$ & 131 (92.9\%) & 7 (4.9\%) & $3(2.1 \%)$ \\
\hline $\begin{array}{l}\text { Osteoporosis is common in women } \\
\text { than men }\end{array}$ & $136(96.4 \%)$ & $4(2.8 \%)$ & $1(0.7 \%)$ \\
\hline $\begin{array}{l}\text { Bones are strongest between the } \\
\text { ages of } 20 \text { to } 50 \text { years }\end{array}$ & $125(88.7 \%)$ & $11(7.8 \%)$ & $5(3.5 \%)$ \\
\hline $\begin{array}{l}\text { Early menopause is a risk factor for } \\
\text { osteoporosis }\end{array}$ & $136(96.5 \%)$ & $3(2.1 \%)$ & $2(1.4 \%)$ \\
\hline $\begin{array}{l}\text { Excessive alcohol intake is a risk } \\
\text { factor for osteoporosis }\end{array}$ & 124 (87.9\%) & 4 (2.8\%) & $13(9.2 \%)$ \\
\hline $\begin{array}{l}\text { Sun light reduces the risk of getting } \\
\text { osteoporosis }\end{array}$ & $128(90.8 \%)$ & 12 (8.5\%) & $1(0.7 \%)$ \\
\hline $\begin{array}{l}\text { Lack of exercise is a risk factor for } \\
\text { osteoporosis }\end{array}$ & $123(87.2 \%)$ & $11(7.8 \%)$ & $7(4.96 \%)$ \\
\hline $\begin{array}{l}\text { Awareness of HRT in prevention of } \\
\text { osteoporosis }\end{array}$ & 131 (92.9\%) & $4(2.8 \%)$ & $6(4.2 \%)$ \\
\hline $\begin{array}{l}\text { High chance of sustaining a } \\
\text { fracture if the previous history of } \\
\text { fragility fractures }\end{array}$ & 131 (92.9\%) & $3(2.1 \%)$ & 7 (4.96\%) \\
\hline $\begin{array}{l}\text { Family history predisposes to } \\
\text { osteoporosis }\end{array}$ & $101(71.6 \%)$ & $25(17.7 \%)$ & 15 (10.6\%) \\
\hline $\begin{array}{l}\text { low BMI is risk factor for } \\
\text { osteoporosis }\end{array}$ & $90(63.8 \%)$ & $41(29.1 \%)$ & $10(7.1 \%)$ \\
\hline $\begin{array}{l}\text { Osteoporosis increases risk of } \\
\text { fractures }\end{array}$ & 131 (92.9\%) & $4(4.2 \%)$ & $6(2.8 \%)$ \\
\hline $\begin{array}{l}\text { Physical activity is beneficial for } \\
\text { osteoporosis }\end{array}$ & $121(85.8 \%)$ & $16(11.3 \%)$ & 4 (2.8\%) \\
\hline $\begin{array}{l}\text { If you have osteoporosis, you } \\
\text { become shorter due to bent spine }\end{array}$ & $106(75.1 \%)$ & $21(14.89 \%)$ & $14(9.9 \%)$ \\
\hline Osteoporosis is treatable disease & $107(75.9 \%)$ & $31(21.98 \%)$ & $3(2.1 \%)$ \\
\hline $\begin{array}{l}\text { There are no effective treatments } \\
\text { for osteoporosis available }\end{array}$ & $73(51.8 \%)$ & $52(36.9 \%)$ & $16(11.3 \%)$ \\
\hline $\begin{array}{l}\text { Calcium supplements and Vitamin } \\
\text { D can prevent osteoporosis }\end{array}$ & 129 (91.5\%) & $8(5.7 \%)$ & $4(2.8 \%)$ \\
\hline
\end{tabular}

Out of 141 respondents, 127 (90.1\%) had good knowledge and 14 (9.9\%) had poor knowledge $\mathrm{p}$-value $<0.01$. There was no significant difference in the level of knowledge on osteoporosis among the health professionals' subgroups (age groups, sex, experience, and speciality) as shown in Table 3.

Table 3: Level of knowledge on osteoporosis among the health professionals' subgroups

\begin{tabular}{|c|c|c|c|c|c|}
\hline & \multirow[t]{2}{*}{ Category } & \multicolumn{2}{|c|}{ Degree of knowledge } & \multirow[t]{2}{*}{ No } & \multirow[t]{2}{*}{$P$ value } \\
\hline & & Good & Poor & & \\
\hline All respondents & $\begin{array}{l}\text { All respondents } \\
\text { less than } 40\end{array}$ & $\begin{array}{l}127(90.1 \%) \\
79(89 \%)\end{array}$ & $\begin{array}{l}14(9.9 \%) \\
10(11 \%)\end{array}$ & $\begin{array}{l}141 \\
89\end{array}$ & $<0.01$ \\
\hline Age groups & $\begin{array}{l}\text { more than } 40 \\
\text { All Groups } \\
\text { medical } \\
\text { surgical }\end{array}$ & $\begin{array}{l}48(92 \%) \\
127(90 \%) \\
29(21 \%) \\
31(22 \%)\end{array}$ & $\begin{array}{l}4(8 \%) \\
14(10 \%) \\
0(0 \%) \\
4(3 \%)\end{array}$ & $\begin{array}{l}52 \\
141 \\
29 \\
35\end{array}$ & 0.4897 \\
\hline Specialties & $\begin{array}{l}\text { primary care } \\
\text { nurse } \\
\text { All Groups }\end{array}$ & $\begin{array}{l}21(15 \%) \\
46(33 \%) \\
127(90 \%)\end{array}$ & $\begin{array}{l}2(1 \%) \\
8(6 \%) \\
14(10 \%)\end{array}$ & $\begin{array}{l}23 \\
54 \\
141\end{array}$ & 0.0591 \\
\hline Gender & $\begin{array}{l}\text { male } \\
\text { female } \\
\text { All Groups } \\
\text { less than } 10 \\
10-20\end{array}$ & $\begin{array}{l}59(42 \%) \\
68(48 \%) \\
127(90 \%) \\
57(40 \%) \\
53(38 \%)\end{array}$ & $\begin{array}{l}4(3 \%) \\
10(7 \%) \\
14(10 \%) \\
9(6 \%) \\
4(3 \%)\end{array}$ & $\begin{array}{l}63 \\
78 \\
141 \\
66 \\
57\end{array}$ & 0.2030 \\
\hline Experience & $\begin{array}{l}\text { more than } 20 \\
\text { All Groups }\end{array}$ & $\begin{array}{l}17(12 \%) \\
127(90 \%)\end{array}$ & $\begin{array}{l}1(1 \%) \\
14(10 \%)\end{array}$ & $\begin{array}{l}18 \\
141\end{array}$ & 0.1730 \\
\hline
\end{tabular}




\section{Discussion}

Osteoporosis is a substantial health problem, particularly with an increase in ageing population. The cornerstone of prevention of osteoporosis is to improve knowledge and awareness among health professionals. Physicians in practice have only limited information about the proper and best treatment strategies for osteoporosis [8]. Although there were many studies described osteoporosis knowledge in populations, only scarce data addressed osteoporosis knowledge among health professionals [9].

This study explored the knowledge of health professional on osteoporosis in Saudi Arabia. In our study, $90 \%$ of the study group expressed good knowledge on osteoporosis which is significantly high. These findings are almost in accordance with the results of another study concluding that $88 \%$ of physicians had a good knowledge of osteoporosis [10]. Furthermore, Saeedi et al. described a range of osteoporosis knowledge between $36.5 \%$ and $92.2 \%$ among physicians [11]. Moreover, German study reported good knowledge of osteoporosis in $83 \%$ of primary care physicians [12]. On the other hand, some studies reported a bit low level of osteoporosis knowledge. In 2013 Al-Musa et al. described an average level of knowledge of $67 \%$ [13]. Another study conducted in 490 primary care physicians, 50\% demonstrated adequate knowledge of calcium and vitamin D supplementation, $51 \%$ were aware of the main therapeutic purposes of osteoporosis [14].

Concerning the questions about osteoporosis, the majority of the respondents demonstrated a good level of knowledge; however, a large gap in knowledge of osteoporosis was detected in two questions assessing symptoms and treatment of osteoporosis with correct answers only of $56 \%$ and $73 \%$ respectively. Beshyah et al. described poor knowledge about osteoporosis treatment among practising physicians [15]. These results lower than what we observed and it could be explained by several reasons including; the difference in study samples, methods of evaluation of knowledge level and the type of the questions in the assessment questionnaires.

About age groups and length of experience, no statistically significant differences in the degree of osteoporosis knowledge between the various groups, although several studies demonstrated a significant inverse relation between physicians' age and knowledge about osteoporosis [16] [17] [18]. This discrepancy is likely attributed to our small sample, but could also be linked to the heterogeneity of our study population.

In this study, health professional gender did not affect the level of knowledge about osteoporosis, while other studies described that females are more knowledgeable than men [12] [18] [19].
In the present study, the degree of knowledge among the different health professionals' subgroups (medical, surgical, primary health care and nursing) showed no significant differences. However, one previous report showed an increased degree of knowledge in family physicians than did general practitioners [16].

Of note, our study has several limitations; the cross-sectional design decreased the power of the study and outcome bias cannot be excluded due to the small sample. A large sample would have led to a better conclusion.

In conclusion, this present study showed that health professionals have a good knowledge about osteoporosis, but there is no significant difference in osteoporosis knowledge between the health professional subgroups (age groups, sex, experience, and speciality). However, there are a few gaps in knowledge that need to be addressed by adopting educational programs for health professionals to robust patient care and decrease disease burden.

\section{References}

1. Wright NC, Looker AC, Saag KG, Curtis JR, Delzell ES, Randall $S$, et al. The recent prevalence of osteoporosis and low bone mass in the United States based on bone mineral density at the femoral neck or lumbar spine. J Bone Miner Res. 2014; 29(11):2520-6. https://doi.org/10.1002/jbmr.2269 PMid:24771492

PMCid:PMC4757905

2. Pande KC. Prevalence of low bone mass in healthy Indian population. J Indian Med Assoc. 2002; 100(10):598-600, 602. PMid: 12452513

3. Kanis J. Assessment of osteoporosis at the primary health care level. World Health [Internet]. 2007; 339. Available from: http://www.shef.ac.uk/FRAX/pdfs/WHO_Technical_Report.pdf

4. Shams J, Spitzer AB, Kennelly AM, Tosi LL. Bone quality: Educational tools for patients, physicians, and educators. Clin Orthop Relat Res. 2011; 469(8):2248-59.

https://doi.org/10.1007/s11999-011-1809-y PMid:21400004 PMCid:PMC3126939

5. Oh SM, Song BM, Nam BH, Rhee Y, Moon SH, Kim DY, et al. Development and validation of osteoporosis risk-assessment model for Korean men. Yonsei Med J. 2016; 57(1):187-96. https://doi.org/10.3349/ymi.2016.57.1.187 PMid:26632400 PMCid:PMC4696952

6. Goelz T, Wuensch A, Stubenrauch S, Ihorst G, de Figueiredo M Bertz H, et al. Specific training program improves oncologists' palliative care communication skills in a randomized controlled trial. $\mathrm{J}$ Clin Oncol. 2011; 29(25):3402-7.

https://doi.org/10.1200/JCO.2010.31.6372 PMid:21825268

7. Alkhamis A. Health care system in Saudi Arabia: An overview. East Mediterr Heal J. 2012; 18(10):1078-9. https://doi.org/10.26719/2012.18.10.1078

8. Otmar R, Reventlow SD, Nicholson GC, Kotowicz MA, Pasco JA. General medical practitioners' knowledge and beliefs about osteoporosis and its investigation and management. Arch Osteoporos. 2012; 7(1-2):107-14. https://doi.org/10.1007/s11657012-0088-x PMid:23225288

9. Werner P. Knowledge about osteoporosis: Assessment, correlates and outcomes. Osteoporosis International. 2005; 
16:115-27. https://doi.org/10.1007/s00198-004-1750-y PMid:15517187

10. Ha Y-C, Lee Y-K, Lim Y-T, Jang S-M, Shin CS. Physicians' Attitudes to Contemporary Issues on Osteoporosis Management in Korea. J Bone Metab. 2014; 21(2):143.

https://doi.org/10.11005/ibm.2014.21.2.143 PMid:25006571

\section{PMCid:PMC4075268}

11. Saeedi MY, Al-amri F, Mohamed A, Ibrahim AK. Knowledge, attitude and practice towards osteoporosis among primary health care physicians in Riyadh, Saudi Arabia. Sci J Public Heal. 2014; 2(6):624-30.

12. Chenot R, Scheidt-Nave C, Gabler S, Kochen MM, Himmel W. German primary care doctors' awareness of osteoporosis and knowledge of national guidelines. Exp Clin Endocrinol Diabetes. 2007; 115(9):584-9. https://doi.org/10.1055/s-2007-981454 PMid:17943692

13. Al-musa H, Alassmi M, Almoria A, Alghamdi H, Alfaifi S. Knowledge, practice and barriers in management of Osteoporosis. 2013; 24(4):429-34.

14. Fogelman Y, Goldshtein I, Segal E, Ish-Shalom S. Managing osteoporosis: A survey of knowledge, attitudes and practices among primary care physicians in Israel. PLoS One. 2016; 11(8). https://doi.org/10.1371/journal.pone.0160661 PMid:27494284 PMCid:PMC4975485
15. Beshyah SA, Mehri W Al, Khalil AB. Osteoporosis and Its Management: Knowledge, Attitudes and Practices of Physicians in United Arab Emirates. 2013; 270-9.

16. Pérez-Edo L, Ciria Recasens M, Castelo-Branco C, Orozco López P, Gimeno Marqués A, Pérez C, et al. Management of osteoporosis in general practice: a cross-sectional survey of primary care practitioners in Spain. Osteoporos Int. 2004 15(3):252-7. https://doi.org/10.1007/s00198-003-1569-y PMid: 14745487

17. Blazkova S, Vytrisalova M, Palicka V, Stepan J, Byma S, Kubena AA, et al. Osteoporosis risk assessment and management in primary care: Focus on quantity and quality. $\mathrm{J}$ Eval Clin Pract. 2010; 16(6):1176-82. https://doi.org/10.1111/j.13652753.2009.01289.x PMid:20545796

18. Werner P, Vered I. Management of osteoporosis: A survey of Israeli physicians' knowledge and attitudes. Isr Med Assoc J. 2000; 2(5):361-4. PMid:10892390

19. Taylor JC, Sterkel B, Utley M, Shipley M, Newman S, Horton $\mathrm{M}$, et al. Opinions and experiences in general practice on osteoporosis prevention, diagnosis and management. Osteoporos Int. 2001; 12(10):844-8. https://doi.org/10.1007/s001980170035 PMid:11716187 